Jurnal Akuntansi Manajerial

ISSN (E): 2502-6704

Vol. 6, No. 1 Januari - Juni 2021: 1-24
Dipublikasikan oleh Fakultas Ekonomi dan Bisnis

Universitas 17Agustus 1945 Jakarta

http://journal.uta45jakarta.ac.id/index.php/JAM

\title{
Pengkreditan Pajak Penghasilan Pasal 24 Sebagai Perencanaan Pajak Yang Efektif
}

\author{
Benyamin Melatnebar \\ Universitas Buddhi Dharma \\ e-mail : benjaminwuarmanuk_81@yahoo.com
}

\begin{abstract}
ABSTRAK
Penelitian ini bertujuan untuk melakukan analisa berkaitan dengan pemanfaatan pajak penghasilan pasal 24 sebagai metode untuk melakukan pengkreditan pajak pada perusahaan. Penggunaan pajak penghasilan pasal 24 belum menjadi perhatian banyak perusahaan untuk mengurangi besarnya pajak penghasilan terutang. Dari hasil penelitian diperoleh hasil bahwa perusahaan dalam negeri yang ikut menanamkan saham di luar negeri, telah mengambil kesempatan untuk memanfaatkan pajak penghasilan pasal 24 sebagai pengkreditan pajaknya. Tetapi pemakaian kredit pajak penghasilan pasal 24 dapat dilakukan bilamana wajib pajak harus mengajukan ke kantor pelayanan pajak dimana dia berdomisili dengan cara menyampaikan Laporan Tahunan SPT dengan menyerahkan sejumlah dokumen yang menyatakan: Laporan keuangan dari luar negeri, fotokopi SPT (Surat Pemberitahuan) sudah dilaporkan ke luar negeri, dan pengembalian pajak asing (bila ada). Sehingga membantu perusahaan untuk menekan besarnya laba kena pajak
\end{abstract}

\section{ABSTRACT}

This study aims to analyze the income tax article 24 usage as a method for crediting taxes to companies. The use of income tax article 24 has not become the concern of many companies to reduce the amount of income tax payable. From the research results, it is found that domestic companies that participate in investing in shares abroad have taken the opportunity to take advantage of income tax article 24 as a foreign tax credit. However, the use of foreign tax credits can be made when a taxpayer has to submit to the tax service office where he is domiciled by submitting an Annual SPT Report by submitting a number of documents stating: Financial reports from abroad, SPT (Tax Returns) photocopies have been reported abroad, and foreign tax returns (if any). Thus helping companies to reduce the amount of taxable profit.
Info Artikel

Diterima: 14 April, 2021

Revisi: 03 Mei 2021

Dipublikasi Online: $30 \mathrm{Juni}$ 2021

Kata kunci :

Pajak Penghasilan Pasal 24, SPT, Pengkreditan Pajak.

\section{Article History}

Received: April 14, 2021

Revised: May 03, 2021

Published Online: Juny 30,2021

\section{Keywords:}

Income Tax Article 24, Tax

Return,

Tax Crediting. 
Jurnal Akuntansi Manajerial

ISSN (E): 2502-6704

Vol. 6, No. 1 Januari - Juni 2021: 1-24
Dipublikasikan oleh Fakultas Ekonomi dan Bisnis

Universitas 17Agustus 1945 Jakarta

http://journal.uta45jakarta.ac.id/index.php/JAM

\section{PENDAHULUAN}

Pemerintah senantiasa mendukung masyarakatnya dalam setiap aktivitasnya untuk menuju pada kesejahteraan rakyat yang hakiki. Program - program untuk mendukung masyarakat mengembangkan lahan pertanian yang baik sehingga menghasilkan panenan padi yang maksimal. Posisi Indonesia sebagai Negara agraris sebenarnya sangat menguntungkan Indonesia untuk bisa unggul di bidang pertanian. Namun menjadi pertanyaan apakah pertanian Indonesia bisa unggul di kancah internasional. Bagaimana Indonesia bisa unggul di bidang pertanian, bila masih melakukan impor dari luar negeri untuk memperoleh cadangan beras menjelang hari raya. Sehingga pemerintah harus melakukan perubahan haluan dengan mendukung sektor lainnya yakni sektor perpajakan.

Sektor perpajakan merupakan salah satu lahan yang bisa digenjot oleh pemerintah untuk penerimaan Negara. Program yang telah dijalankan oleh direktorat jenderal pajak seperti sunset policy dan tax amnesty telah berjalan dengan sangat baik dan memberikan kontribusi yang cukup signifikan bagi Negara. Memang tidak terlalu maksimal tapi setidaknya membuat wajib pajak untuk mendapatkan keringanan pajak, namun juga adanya keinginan wajib pajak untuk melakukan pelaporan pajak. Ada yang melakukan deklarasi dalam negeri, deklarasi luar negeri bahkan juga melakukan repatriasi. Ada baiknya direktorat jenderal pajak bisa melakukan gebrakan baru lagi untuk menunjang penerimaan Negara di sektor pajak. Jenis - jenis pajak penghasilan sebenarnya banyak yang dapat diserap juga oleh Negara. Ada SPT (Surat Pemberitahuan) Pajak Pertambahan Nilai (PPN) untuk melaporkan faktur pajak masukan dan faktur pajak keluaran, Pajak Penghasilan Pasal 21 yang mengatur tentang pemotongan pajak atas gaji karyawan, Pajak penghasilan Pasal 23 yang mengatur tentang pemotongan pajak atas belanja jasa sesuai PMK 244 tahun 2008 jo PMK 141 tahun 2015, Pajak Penghasilan Pasal 25 yang mengatur tentang angsuran pajak dan Pajak Penghasilan pasal 24 yang mengatur tentang kredit pajak luar negeri.

Pajak Penghasilan Pasal 24 merupakan salah satu jenis pajak yang bisa digunakan oleh pengusaha kena pajak untuk melakukan pengkreditan pajak pada SPT Tahunan. Sebenarnya apakah yang dimaksud dengan mengkreditkan pajak. Mengkreditkan pajak 
Jurnal Akuntansi Manajerial

ISSN (E): 2502-6704

Vol. 6, No. 1 Januari - Juni 2021: 1-24
Dipublikasikan oleh Fakultas Ekonomi dan Bisnis

Universitas 17Agustus 1945 Jakarta

http://journal.uta45jakarta.ac.id/index.php/JAM

menggunakan pajak penghasilan PPh pasal 21, 22 dan 23. Misalkan Kurang bayar pajak Pajak Penghasilan Badan sebesar Rp. 100.000.000,00. Pajak Penghasilan pasal 23 terkait belanja atas jasa sebasar Rp. 30.000.000,00 sehingga nominal kurang bayar (kb) pajaknya jadi senilai Rp. 70.000.000,00. Adapun nominal kurang bayar pajak ke Negara justru menjadi lebih kecil after dikurangi $\mathrm{PPh}$ pasal 23. Hal ini yang bisa dimanfaatkan oleh perusahaan untuk bisa memanfaatkan jenis - jenis pajak yang bisa dikreditkan. Sebenarnya ini yang dinamakan perencanaan pajak. Wuarmanuk (2019) menyatakan bahwa Tax Planning atau istilah kerennya perencanaan pajak diartikan sebagai metode atau cara untuk merencanakan pajak. Supaya kewajiban membayar pajak ke Negara menjadi lebih kecil. Setiap perusahaan diperkenankan untuk melakukan perencanaan pajak, karena perencanaan pajak ini sesuai dengan regulasi atau undang - undang perpajakan yang berlaku. Adapun keinginan penulis untuk menyuguhkan sebuah mekanisme pengkreditan pajak dari sektor pajak penghasilan pasal 24. Sehingga dari konsep tersebut penulis ingin melakukan riset berkaitan dengan Pajak Penghasilan Pasal 24 sebagai metode pengkreditan pajak yang efektif. Dari beberapa jenis pajak penghasilan yang dapat dikreditkan, pajak penghasilan pasal 24 memang sedikit lebih rumit perhitungannya. Pengakuan terhadap pendapatan di luar negeri dapat ditambah dengan penghasilan yang ada di dalam negeri untuk menghitung pajak untuk dapat menghitung batas maksimum kredit pajak. Pengkreditan pajak PPh pasal 24 dianggap memberikan keringanan bagi perusahaan ketika membayarkan Pajak penghasilan terutang badan, karena pajak penghasilan pasal 24 untuk menekan besarnya laba kena pajak perusahaan. Karena alasan inilah mengapa penulis mengambil judul penelitian Pengkreditan Pajak Penghasilan Pasal 24 sebagai Perencanaan Pajak yang Efektif.

Pajak dapat dengan leluasa dikatakan sebagai tanggung jawab warga negara dalam peran sukarela dan kasat mata warga negara dalam peran sukarela oleh anggota masyarakat untuk mendukung berbagai kebutuhan negara dalam pembangunan nasional, tanpa kompensasi langsung; dalam hukum perpajakan untuk kesejahteraan bangsa dan negara. Dengan demikian perbaikan kondisi usaha di tingkat nasional dan internasional akan meningkatkan pendapatan WP Badan Dalam Negeri (DN). PPh pasal 24 yang telah dipungut di Luar Negeri (LN) untuk penghasilan WPLN. Adapun Pajak 
Jurnal Akuntansi Manajerial

ISSN (E): 2502-6704

Vol. 6, No. 1 Januari - Juni 2021: 1-24
Dipublikasikan oleh Fakultas Ekonomi dan Bisnis

Universitas 17Agustus 1945 Jakarta

http://journal.uta45jakarta.ac.id/index.php/JAM

luar negeri yang dikenakan atas penghasilan wajib pajak daerah (WPDN) dapat dihitung atas pajak yang dibayarkan untuk tahun pajak berjalan, pada jumlah pajak yang dipungut di luar negeri tetapi tidak boleh melebihi perhitungan pajak yang dibayarkan berdasarkan Undang-undang No. 10 /1994.

WP yang mampu menekan besarnya pajak untuk seluruh penghasilan yang diterima, apakah itu di luar maupun di dalam negeri didefinisikan sebagai kredit pajak. Dalam rangka untuk menghindari pengenaan pajak berganda di perusahaan serta memberikan treatment pajak yang sama, pajak yang bisa dikurangkan dari pendapatan perusahaan sendiri yang diterima di luar negeri dapat dikurangkan dari pajak teruntuk tahun yang sama. Pendapatan dalam bentuk dividen dieksekusi di tahun pajak ketika manfaat dari penghasilan itu diterima.

Berikut mekanisme pengajuan pengkreditan $\mathrm{PPh}$ yang dieksekusi di luar negeri menurut PERMENKEU 192/ PMK.03 / 2018 :

1. PPh berasal dari luar negeri yang notabene exclude dalam pengenaan pajak di Indonesia yang mana ditentukan menurut poin - poin sebagai berikut:

Hasil PPh terutang, dipotong atau dibayarkan di luar negeri sesuai dengan ketentuan Perjanjian Pajak, dalam hal Perjanjian Pajak yang berlaku:

a. Total Pajak Penghasilan dari luar negeri

b. Angka tertentu dihitung dengan perbandingan berikut:

Jumlah pendapatan di Negara A : Total pendapatan (DN dan LN) x Jumlah Pajak Penghasilan Terutang

2. Jika penghasilan yang berasal dari LN ini memang berasal dari satu atau dua lebih negara sehingga perhitungan Pajak Penghasilan Pasal 24 tersebut dikhususkan untuk masing-masing negara.

3. Dalam konteks pasangan istri suami sebagai WPDN yang menghendaki dan membuat kesepakatan tertulis bersama tentang pembagian harta dan penghasilan, atau bila sang istri menghendaki untuk melaksanakan kewajiban dan hak perpajakannya sekehendak hati, sehingga nominal PPh di luar negeri 
Jurnal Akuntansi Manajerial

ISSN (E): 2502-6704

Vol. 6, No. 1 Januari - Juni 2021: 1-24
Dipublikasikan oleh Fakultas Ekonomi dan Bisnis

Universitas 17Agustus 1945 Jakarta

http://journal.uta45jakarta.ac.id/index.php/JAM

yang diterima masing-masing baik oleh istri atau suami akan ditetapkan menurut hal-hal berikut ini:

a. Nominal PPh terutang, dibayar maupun dipotong di luar negeri (LN) terkait pendapatan yang diperoleh berasal dari sumber pendapatan di luar negeri teruntuk istri atau suami menurut regulasi aturan perpajakan, sesuai Kesepakatan Perpajakan berlaku atau yang telah disahkan;

b. Besarnya PPh di luar negeri terkait pendapatan yang diperoleh dari sumber pendapatan di luar negeri bagi setiap perempuan atau lakilaki; dan

c. Nominal tertentu yang dikalkulasikan menurut rata-rata pendapatan yang diterima dari asal pendapatan diperoleh di luar negeri oleh setiap perempuan atau laki-laki dalam format $\mathrm{PPh}$ yang dikalikan dengan status $\mathrm{PPh}$, yang nominalnya sama jumlahnya dengan $\mathrm{PPh}$ yang terutang. dilaksanakan secara individu.

4. Terkait pedapatan yang diterima yang berasal dari penghasilan di luar negeri, adapun nilai PPh yang ditentukan berikut ini:

a. Nominal yang sama dengan $\mathrm{PPh}$ atau setengah dari $\mathrm{PPh}$ yang diperoleh WPDN, bagi Wali Amanat di negara lain yang notabene lebih kecil dari PPh pada tingkatan Trust; dan

b. Sebagian besar PPh yang memang diterima oleh wajib pajak dalam negeri, yang dikhususkan bagi perwalian di luar negeri yang tak kena PPh pada tingkatan Trust.

5. Pengenaan PPh terkait eksekusi pembayaran PPh Final (UU PPh 4 ayat 2) dan / atau pendapatan terkait dengan pajak tersendiri (Pajak Penghasilan Pasal 8 ayat (1 dan 4) UU) tak boleh ditambahkan dengan pendapatan lain, baik itu diterima secara lokal, serta uang yang diterima dari luar negeri.

6. Untuk melakukan importasi Pajak, WP memiliki kewajiban untuk melakukan penyampaian bukti pemenuhan pembayaran PPh LN untuk Wajib Pajak Dalam Negeri terkait PPh Luar Negeri itu dengan cara - cara sebagai berikut;

a. Copy payment evidence atau bukti potong pajak penghasilan luar negeri; atau 
Jurnal Akuntansi Manajerial

ISSN (E): 2502-6704

Vol. 6, No. 1 Januari - Juni 2021: 1-24
Dipublikasikan oleh Fakultas Ekonomi dan Bisnis

Universitas 17Agustus 1945 Jakarta

http://journal.uta45jakarta.ac.id/index.php/JAM

b. Beberapa salinan bukti mungkin menunjukkan pembayaran atau pemotongan Pajak Asing.

c. Bukti pembayaran Pajak Penghasilan Luar Negeri paling sedikit memuat keterangan berupa nama Wajib Pajak Dalam Negeri serta nominal pajak penghasilan luar negeri tersebut.

d. Terkait Wajib Pajak Dalam Negeri memperoleh hasil usaha (bisnis) dan / atau pendaptan yang diperoleh dari Pengawas tingkat penghasilan LN pada tingkat Trust, evidence berupa kepatuhan Pembayaran PPh yang bisa di trade dengan cana membuat pemberitahuan $\mathrm{PPh}$ tahunan yang notabene dikirim kepada branch atau juga kepada perwakilan dari Wajib Pajak Dalam Negeri di luar negeri dan / atau juga dari restitusi pajak penghasilan tahunan ataupun payment evidence terkait pajak penghasilan Luar Negeri oleh Trust

7. Adapan bila terjadi adanya perubahan nominal pendapatan dari luar negeri, WP wajib melakukan adjustment terkait Pajak Restitusi Tahunan yang bersangkutan dengan cara menyampaikan dokumen-dokumen yang berkaitan dengan perubahan tersebut.

8. Jika sebagai akibat dari penyesuaian SPT maka retribusi yang dikenakan dikurangi, maka retribusi yang lebih rendah tidak dikenakan bunga.

9. Apabila karena pembetulan SPT menyebabkan kelebihan pembayaran, adanya kelebihan nominal tersebut dapat direstitusikan kepada WP setelah dilakukan kalkulasi dan eksekusi tax payment lainnya.

Sebagai ilustrasi:

Misalkan Wajib Pajak Dalam Negeri, PT Angela di tahun 2020 memperoleh penghasilan dengan rincian berikut ini:

a. Di Sebuah Negara Xanta, PT Angela memperoleh penghasilan atas operasional Rp1.000.000.000,00 lalu dipotong Pajak di Luar Negeri sebesar Rp 300.000.000,00;

b. Di negara Yanta, PT Angela memperoleh penghasilan atas bunga sebesar Rp3.000.000.000,00 lalu dipotong Pajak Luar Negeri sebesar Rp. 450.000.000,00, dan tidak ada pengurangan pendapatan bruto dari bunga; 
Jurnal Akuntansi Manajerial

ISSN (E): 2502-6704

Vol. 6, No. 1 Januari - Juni 2021: 1-24
Dipublikasikan oleh Fakultas Ekonomi dan Bisnis

Universitas 17Agustus 1945 Jakarta http://journal.uta45jakarta.ac.id/index.php/JAM

c. Pada negara Zanta, PT Angela telah mengalami kehilangan pendapatan atas aset sebesar Rp 250.000.000,00; dan

d. Penghasilan Domestik senilai Rp 4.000.000.000,00.

Diketahui tidak adanya kesepakatan pajak antara Indonesia dengan negara Xanta, negara Yanta, dan juga negara Zanta. Kemudian jumlah pajak yang terutang pada semua penghasilan dihitung sebagai berikut:

a. Pendapatan keseluruhan di luar negeri:

1) Negara Xanta (operational income) Rp 1.000.000.000,00

2) Negara Yanta (interest income) Rp 3.000.000.000,00

3) Negara Zanta (sales losses)

$\underline{\mathrm{Rp}} \quad 0,00$

Total penghasilan

$\operatorname{Rp} 4.000 .000 .000,00$

b. Penghasilan dari dalam negeri Rp. 4.000.000.000,00

c. Total penghasilan $\operatorname{Rp} 8.000 .000 .000,00$

d. Penghasilan kena pajak Rp 8.000.000.000,00

e. PPh terutang (Tarif Progresif Pasal 17 UU PPh) Rp2.000.000.000,00

Besarnya PPh Luar Negeri yang dikenakan untuk setiap jenis pendapatan di setiap negara dibuat sebagai berikut:

a. Penghasilan operasional dari Negara Xanta:

1. Penghasilan Usaha PPh Luar Negeri dari negara Xanta sampai dengan Rp. 300.000.000,00;

2. Jumlah tertentu

$$
\begin{gathered}
=\frac{R p 1.000 .000 .000,00}{R p 8.000 .000 .000,00} \times R p 2.000 .000 .000,00 \\
=R p 250.000 .000,00
\end{gathered}
$$

Dikarenakan sejumlah Rp. 250.000.000,00, ini kurang dari PPh atas penghasilan usaha dari negara Xanta, jumlah pengenaan pajak di luar negeri atas pendapatan 
Jurnal Akuntansi Manajerial

ISSN (E): 2502-6704

Vol. 6, No. 1 Januari - Juni 2021: 1-24
Dipublikasikan oleh Fakultas Ekonomi dan Bisnis

Universitas 17Agustus 1945 Jakarta

http://journal.uta45jakarta.ac.id/index.php/JAM

usaha dari negara Xanta yang memang dikecualikan dari PPh DN hanya senilai tertentu, yaitu Rp250.000.000,00.

b. Pendapatan bunga berasal dari negara Yanta:

1) Pajak Penghasilan di Luar Negeri atas pendapatan bunga dari negara Yanta senilai Rp450.000.000,00;

2) Nominal tertentu

$$
\begin{gathered}
=\frac{R p 3.000 .000 .000,00}{R p 8.000 .000 .000,00} \times R p 2.000 .000 .000,00 \\
=R p \quad 750.000 .000,00
\end{gathered}
$$

Disebabkan jumlah Pajak Penghasilan di LN teruntuk penghasilan bunga dari negara Yanta senilai Rp. 450.000.000,00 lebih kecil bila dibandingkan dengan nominal tertentu, maka jumlah Pajak Penghasilan di Luar Negeri atas pendapatan bunga dari negara Yanta yang notabene bisa dikreditkan dengan PPh terutang di dalam negeri pun senilai PPh Luar Negeri, yaitu senilai Rp. 450.000.000,00.

Sehingga, jumlah Pajak Penghasilan LN yang bisa dikreditkan oleh PT Angela terhadap PPh terutang di DN yakni senilai Rp 700.000.000,00 (Rp250.000.000,00 + Rp450.000.000,00). Adapun kerugian yang diperoleh dari negara Zanta tidak bisa digabungkan dalam mengkalkulasikan Pendapatan Kena Pajak.

Eksekusi pembayaran pajak tidak hanya dilakukan secara lokal tetapi juga internasional. Terkait dengan isu PPh 24 adalah untuk mengontrol hak wajib pajak untuk menggunakan hutang pajak luar negeri untuk membantu mengurangi jumlah pemotongan pajak di Indonesia. Tentunya kewajiban pajak yang harus dibayar di Indonesia bisa berkurang jika pajak dibayarkan wajib pajak di luar negeri, utang pajaknya tidak melebihi pajak yang dibayarkan di Indonesia. Sumber penghasilan kena pajak di luar negeri yang dapat digunakan untuk mengurangi pajak yang dibayarkan di Indonesia adalah sebagai berikut:

1. Keuntungan atau penghasilan dari saham atau surat berharga lainnya, dan manfaat pemindahan saham atau surat berharga lainnya 
Jurnal Akuntansi Manajerial

ISSN (E): 2502-6704

Vol. 6, No. 1 Januari - Juni 2021: 1-24
Dipublikasikan oleh Fakultas Ekonomi dan Bisnis

Universitas 17Agustus 1945 Jakarta

http://journal.uta45jakarta.ac.id/index.php/JAM

2. Pendapatan dalam bentuk sewa terkait pemakaian harta tidak bergerak di negara lain.

3. Pendapatan berupa bunga, royalti, serta pajak sehubungan dengan pemakaian barang pindahan ke negara lain.

4. Penghasilan dalam bentuk remunerasi yang berhubungan dengan aktivitas dan jasa

5. Pendapatan dari BUT Bentuk/ Badan Usaha tetap di luar negeri.

6. Hasil pemindahan sebagian /seluruhnya hak atas penambangan/ penyertaan keuangan atau penggunaan perusahaan pertambangan.

7. Manfaat pengalihan aset tetap.

8. Keuntungan dari pengalihan aset yang menjadi bagian dari Lembaga Tetap (PE).

Jika jumlah pajak luar negeri yang perusahaan gunakan sebagai hutang pajak di Indonesia, telah dikurangi atau dikembalikan kepada perusahaan, sehingga nilai kredit perusahaan lebih kecil dari pajak yang perusahaan bayarkan di Indonesia, maka perusahaan harus membayar jumlah yang terutang ke kantor pelayanan pajak Indonesia. Jika kurs valuta asing berubah, WP memiliki kewajiban untuk membuat pembetulan SPT pada tahun pajak yang bersangkutan. Saat perusahaan menyelesaikan kewajiban perpajakan, jangan lupa untuk membayar pajak lainnya seperti Pajak Penghasilan Pasal 23, Pasal 25 sehubungan dengan angsuran pajak, dan pajak lainnya.

Contoh dan Cara Penghitungan Pajak Penghasilan pasal 24

Misalnya PT XYZ pada tahun 2019 menerima penerimaan di Indonesia senilai Rp 25.000.000.000,00 dan di negara Kilo Rp10.000.000.000,00. Perkiraan pajak negara Kilo 20\%. Total penghasilan yang dicatat senilai Rp 35.000.000.000,00 (Penghasilan di DN + penghasilan di LN)

Total Hutang Pajak (HP):

$$
25 \% \times R p 35.000 .000 .000,00=R p 8.750 .000 .000,00
$$

Pajak penghasilan yang sebaiknya diakui: 
Jurnal Akuntansi Manajerial

ISSN (E): 2502-6704

Vol. 6, No. 1 Januari - Juni 2021: 1-24
Dipublikasikan oleh Fakultas Ekonomi dan Bisnis

Universitas 17Agustus 1945 Jakarta

http://journal.uta45jakarta.ac.id/index.php/JAM

$$
\frac{\text { Penghasilan di luar negeri }}{\text { penghasilan kotor }} \times \text { Total penghasilan kotor }
$$

$$
\frac{R p 10.000 .000 .000,00}{R p 35.000 .000 .000,00} \times R p 8.750 .000 .000,00=R p 2.500 .000 .000,00
$$

Oleh sebab itu, PPh yang dieksekusi untuk dibayarkan di luar negeri sebesar Rp 2.500.000.000,00. Sehingga, jumlah yang terbatas ini pada akhirnya digunakan sebagai pengurang pajak dalam negeri. Perlu diingat bahwa, jika Wajib Pajak ingin mengajukan SPT daerah, perusahaan harus melaporkannya terlebih dahulu kepada Kepala Kantor Pelayanan Pajak (KPP) kemudian melaporkannya saat melaporkan SPT tahunan. Setelah mengetahui pajak penghasilan pasal 24 dan statistiknya. Kami berharap wajib pajak luar negeri dapat memenuhi kewajiban dan hak perpajakannya.

Indonesia dikenal sebagai Negara agraris, dimana penduduknya bermata pencaharian sebagai petani. Iklim Indonesia yang panas menunjang warganya untuk menanam padi dan menjualnya kepada masyarakat dalam rangka memenuhi setiap kebutuhan pokok masyarakat hampir di seluruh pelosok di Indonesia. Namun menjadi pertanyaan apakah sektor pertanian mampu bersaing di kancah Internasional untuk membawa Indonesia dari sebuah Negara berkembang menjadi Negara maju. Menggunakan metode tradisional dalam melakukan pembajakan sawah menggunakan tenaga kerbau, dirasa sangat konvensional dan harus ditinggalkan. Ada baiknya kita mengadopsi teknologi pembajakan sawah yang canggih yang dikembangkan oleh Negara - Negara maju seperti Jerman atau Belperusahaan untuk melakukan pembajakan sawah. Kita mungkin pernah mendengar atau kaget ketika ada berita di radio atau media lain bahwa $40 \%$ aset bank swasta Singapura ternyata penuh dengan barang-barang milik pribadi Indonesia. Potensi perpajakan suatu negara asing ternyata sangat besar jika tidak dikelola dengan baik.

Wajib pajak yang memperoleh penghasilan dari kegiatan usaha di luar negeri dapat berasal dari berbagai sumber usaha, seperti penerimaan dari surat berharga dan surat berharga lainnya, pendapatan bunga, royalti, pembayaran 
Jurnal Akuntansi Manajerial

ISSN (E): 2502-6704

Vol. 6, No. 1 Januari - Juni 2021: 1-24
Dipublikasikan oleh Fakultas Ekonomi dan Bisnis

Universitas 17Agustus 1945 Jakarta

http://journal.uta45jakarta.ac.id/index.php/JAM

terkait jasa, ketenagakerjaan dan kegiatan lainnya. Kalau dipikir-pikir, wajib pajak seperti ini bisa dikenakan pajak dua kali lipatnya, yaitu kondisi pajak luar negeri dimana dia mendapat keuntungan bisnis dan pajak dari dalam negeri dimana dia menjadi wajib pajak Warga Negara Indonesia (WNI).

Segala hal yang berkaitan dengan masalah perpajakan di atas diatur dalam peraturan perpajakan di Indonesia khususnya PPh Pasal 24. Lantas, apa saja aturan dari PPh pasal 24? Berikut ulasannya. Pajak Penghasilan Pasal $24(\mathrm{PPh}$ Pasal 24) mengatur hak wajib pajak untuk memanfaatkan kewajiban perpajakan luar negerinya. Hal ini agar wajib pajak tidak perlu membayar pajak dua kali lipat seperti yang dijelaskan di atas. PPh pasal 24 mengatur bea masuk yang dikenakan sebagai pengurang dari Indonesia. Dengan kata lain, besarnya pajak yang harus dibayar di Indonesia bisa dikurangi dengan jumlah pajak yang telah mereka bayarkan ke luar negeri. Syarat utamanya adalah jumlah utang pajak di luar negeri tidak melebihi utang pajak yang ingin perusahaan bayarkan di Indonesia. Setelah melihat pengertian di atas, apa sumber penghasilan yang bisa dijadikan sebagai pengurang pajak? Pajak Penghasilan Pasal 24 mengatur tentang sumber-sumber penghasilan yang dapat diperhitungkan sebagai pengurang pajak dalam negeri.

Berikut ini jenis - jenis penghasilan: Uang dari saham dan surat berharga lainnya, keuntungan dari transfer saham serta sekuritas lainnya. Pendapatan lain seperti interest, royalti serta pajak terkait dengan pemakaian harta bergerak. Pendapatan melalui SGU atau sewa guna usaha yang berhubungan dengan pemakaian harta tidak bergerak. Menghargai layanan yang terkait dengan layanan dan aktivitas. Semua keuntungan bentuk usaha tetap (BUT) di luar negeri. Keuntungan dari berkontribusi pada pengeluaran atau pengeluaran pada perusahaan pertambangan. Keuntungan dari pengalihan aset yang menjadi bagian dari Bentuk Usaha Tetap (Permanent Establishment).

\section{Metode Kredit Terbatas dalam PPh Pasal 24}

PPh Pasal 24 mengatur tentang pajak yang terutang atau wajib dibayarkan di luar negeri teruntuk pendapatan yang terutang atau dibayarlan di luar negeri yang notabene bisa dikreditkan terhadap PPh terutang di Indonesia. Karena itu, 
Jurnal Akuntansi Manajerial

ISSN (E): 2502-6704

Vol. 6, No. 1 Januari - Juni 2021: 1-24
Dipublikasikan oleh Fakultas Ekonomi dan Bisnis

Universitas 17Agustus 1945 Jakarta

http://journal.uta45jakarta.ac.id/index.php/JAM

pajak ini langsung dikenakan atas pendapatan yang diperoleh WP. Di luar itu tidak bisa dijadikan pengurang pajak. Hal ini yang dikenal sebagai metode kredit terbatas (ordinary credit method/ limited credit method).

Besarnya PPh Pasal 24 menurut metode kredit terbatas bisa dihitung dengan perhitungan:

Penghasilan Neto Negara A

X PPh Terutang

\section{Penghasilan Kena Pajak}

Untuk lebih jelasnya mari kita simak uraian lengkap ilustrasi dibawah ini:

Pertama-tama perusahaan akan diminta untuk mengisi data nominal pajak yang perusahaan bayarkan di luar negeri untuk mendapatkan ilustrasi mengenai besarnya pajak yang harus dibayarkan di dalam negeri. Jika nilai pajak di luar negeri yang telah perusahaan gunakan sebagai kredit pajak di Indonesia telah berkurang atau dikembalikan, perusahaan tinggal membayar jumlah terutang tersebut ke Kantor Pelayanan Pajak di Indonesia.

Ilustrasi ini akan membantu Perusahaan untuk memahaminya:

PT Ronaldo di Indonesia adalah pemegang saham mayoritas atas Open Sesame United di Inggris. Selama tahun 2014, PT Ronaldo memperoleh keuntungan sebesar USD 500,000.00. Ketentuan Pajak Penghasilan yang berlaku di Inggris adalah $48 \%$ dan Pajak Dividen adalah 38\%. Terdapat dua perhitungan yang digunakan di sini: pajak atas dividen dan pajak atas penghasilan.

Penghitungan pajak atas dividennya adalah sebagai berikut:

Keuntungan Open Sesame United USD 500,000.00. Pajak Penghasilan (Corporate Income Tax) atas Open Sesame United (48\%) USD 240,000.00 (-) USD $260,000.00$ 
Jurnal Akuntansi Manajerial

ISSN (E): 2502-6704

Vol. 6, No. 1 Januari - Juni 2021: 1-24
Dipublikasikan oleh Fakultas Ekonomi dan Bisnis

Universitas 17Agustus 1945 Jakarta

http://journal.uta45jakarta.ac.id/index.php/JAM

Pajak atas dividen (38\%) USD 98,800.00 (-) dividen yang dikirim ke Indonesia adalah sebesar USD 161,200.00 Berapa pajak penghasilan yang bisa dikenakan di Indonesia?

Hanya pajak yang dipungut langsung atas penghasilan yang diperoleh atau diterima di luar negeri (dalam hal ini USD 98,800.00) yang dapat dimasukkan dalam pajak dalam negeri. Selain itu, Pajak Penghasilan Badan (Pajak Penghasilan Badan) di Open Sesame United sebesar USD 240,000.00 mungkin tidak dimasukkan dalam Pajak Penghasilan. Pasalnya, pajak USD 240,000.00 itu tidak langsung dimasukkan ke dalam gaji yang diterima PT Ronaldo dari luar negeri. Namun, pajak dikenakan atas keuntungan Open Sesame United di Inggris.

Proses Teknis Pelaksanaan PPh di Luar Negeri terkait Hutang Pajak di DN. Mekanisme pengenaan pajak atas penghasilan di luar negeri atas pajak di dalam negeri yang ditetapkan dengan Keputusan Menteri Keuangan Nomor 164 / KMK.03 / 2002 sebagai berikut.

1. Penyerahan pajak yang dibayarkan di luar negeri harus dilakukan pada tahun pajak yang sama.

2. Jumlah yang tidak dihargai sama dengan tingginya nilai pajak yang dibayarkan atau dibayarkan di luar negeri. Namun, ada batasan rasio jumlah antara pendapatan asing dan pendapatan kena pajak gperusahaan yang dibayarkan ke masing-masing negara.

Proses pengimporan pajak harus disampaikan kepada Direktur Jenderal Pajak dengan:

1. Laporan Keuangan pendapatan dari luar negeri.

2. Fotokopi Restitusi pajak yang dikirim ke luar negeri.

3. Pengembalian pajak asing.

Pengajuan pajak penghasilan luar negeri dilakukan bersamaan dengan penyampaian SPT tahunan. 
Jurnal Akuntansi Manajerial

ISSN (E): 2502-6704

Vol. 6, No. 1 Januari - Juni 2021: 1-24
Dipublikasikan oleh Fakultas Ekonomi dan Bisnis

Universitas 17Agustus 1945 Jakarta

http://journal.uta45jakarta.ac.id/index.php/JAM

PPh Pasal 24 adalah pengaturan yang mengatur tentang hak Wajib Pajak untuk menggunakan kredit pajaknya di luar negeri, untuk mengurangi jumlah pajak yang dibayarkan di Indonesia. Dengan demikian, jumlah pajak yang terutang di Indonesia dapat dikurangi dengan jumlah pajak yang dibayarkan di luar negeri, selama jumlah pajak yang terutang di luar negeri tidak melebihi pajak yang dibayarkan di Indonesia. Penggunaan kewajiban perpajakan luar negeri dimaksudkan agar wajib pajak bisa dikenakan pajak dua kali lipat

Ada beberapa kasus dimana wajib pajak bertanggung jawab membayar pajak, tidak hanya di Indonesia tetapi juga di negara lain. Oleh karena itu, jenis pajak ini, yaitu Pajak Penghasilan Pasal 24 (Pajak Penghasilan Pasal 24), dapat diberlakukan kepada setiap pengusaha kena pajak. Sumber penerimaan kena pajak yang dapat digunakan untuk mengurangi pajak di Indonesia adalah sebagai berikut:

1. Dana dari saham dan sekuritas lainnya, serta manfaat dividen dan sekuritas lainnya.

2. Pendapatan bunga, royalti dan pajak terkait dengan penggunaan properti bergerak.

3. Penghasilan melalui sewa guna usaha yang berkaitan dengan penggunaan harta tak gerak.

4. Pendapatan berupa hadiah yang berkaitan dengan layanan dan aktivitas

5. Penerimaan Bentuk Usaha Tetap di luar negeri.

6. Hasil dari pemindahan sebagian atau keseluruhan hak penambangan atau tperusahaan partisipasi dalam pembiayaan atau penggunaan perusahaan pertambangan.

Manfaat dari pengalihan aset tetap. Manfaat pengalihan aset yang merupakan bagian dari struktur permanen (Permanent Establishment). Jika jumlah pajak luar negeri yang selama ini perusahaan jadikan sebagai utang pajak di Indonesia, telah dikurangi atau dikembalikan kepada perusahaan, sehingga skor kredit perusahaan tidak cukup untuk membayar pajak yang terutang, di sini perusahaan harus membayar jumlah tersebut kepada kantor pajak Indonesia. Jika penghasilan luar 
Jurnal Akuntansi Manajerial

ISSN (E): 2502-6704

Vol. 6, No. 1 Januari - Juni 2021: 1-24
Dipublikasikan oleh Fakultas Ekonomi dan Bisnis

Universitas 17Agustus 1945 Jakarta

http://journal.uta45jakarta.ac.id/index.php/JAM

negeri berubah, wajib pajak diwajibkan untuk melakukan penyesuaian SPT pada periode pajak yang bersangkutan.

\section{PEMBAHASAN}

Mekanisme pengkreditan atas pajak tahunan menurut UU No 36/ 2008 dalam pasal 24 serta dalam keputusan Menteri keuangan No. 164 / kmk.03 / 2002. Dalam perspektif yang memungkinkan WP untuk mengurangi besarnya hutang PPh terutang di akhir periode tahun pajak, namun bila ada sumber pendapatan dari luar negeri di combine dengan penghasilan dari dalam negeri. Pendapatan yang berhubungan dengan Pasal 24, disingkat Pajak Penghasilan pasal 24, merupakan pajak yang notabene dibayar di LN sehubungan dengan pendapatan di luar negeri yang diperoleh oleh WPDN. Formulir pajak penghasilan pasal 24 di tahun tersebut bisa dijumlahkan ke akumulasi pajak penghasilan yang terutang pada tahun pajak tersebut.

Basically, WPDN dipungut pajak atas semua pendapatan, pendapatan yang diperoleh di dalam negeri dan pendapatan yang diperoleh atau diterima di luar negeri. Di negara lain dimana wajib pajak memberlakukan pajak pendapatan, maka wajib pajak akan membayar atau akan dibayar pajak pendapatan, wajib pajak akan membayar atau membayar pajak atas jumlah tersebut di negara yang bersangkutan (di luar negara). Untuk mengurangi beban pajak berganda yang mungkin timbul akibat pemberlakuan pajak atas penghasilan atau ekspor, besarnya penghasilan WPDN yang memang terhutang di LN bisa dikalkulasi kemudian ditandingkan dengan PPh yang terutang sehubungan dengan semua uang WPDN.

Nominal pajak atas pendapatan WPDN yang dibayar atau dibayarkan di luar negeri dihitung berdasarkan jumlah pajak yang berlaku di negara yang bersangkutan dikalikan dengan jumlah yang diterima di negara yang bersangkutan. Tidak semua pajak yang dibayarkan di luar negeri dikecualikan dari pajak penuh yang dibayarkan di Indonesia. Pasal 24 dari UU No. 17 tahun 2000. Selain itu, mengatur jumlah pajak penghasilan yang dibayarkan di luar negeri yang tidak termasuk dalam pajak yang dibayarkan di Indonesia. 
Jurnal Akuntansi Manajerial

ISSN (E): 2502-6704

Vol. 6, No. 1 Januari - Juni 2021: 1-24
Dipublikasikan oleh Fakultas Ekonomi dan Bisnis

Universitas 17Agustus 1945 Jakarta

http://journal.uta45jakarta.ac.id/index.php/JAM

\section{Saat Mengkonsolidasi Uang Domestik dan Asing}

Konsolidasi pendapatan luar negeri dan penerimaan pajak dalam negeri untuk satu tahun pajak adalah sebagai berikut:

1. Dengan keuntungan dari bisnis yang dibuat selama tahun pajak, hasilnya tersedia.

2. Penghasilan selanjutnya akan dihasilkan dalam tahun pajak di mana pendapatan tersebut diterima.

3. Pendapatan dalam bentuk dividen, dibuat pada tahun pajak pada saat manfaat diterima.

4. Losses yang memang terjadi di luar negeri tidak dapat dimasukkan dalam perhitungan pendapatan.

5. Jika pajak pendapatan luar negeri dipotong kemudian atau dikembalikan, pajak terhutang harus ditambahkan ke jumlah ini pada tahun pemotongan atau pengembalian pajak tersebut.

6. Jika pendapatan LN asalnya dari banyak negara, maka kalkulasi hutang pajak diperuntukkan bagi masing-masing negara.

\section{Menghitung jumlah hutang pajak luar negeri}

Penghitungan penghasilan tidak kena pajak tidak termasuk pembayaran di luar negeri selain kewajiban pajak yang diperbolehkan, sehingga kelebihannya tidak dapat dihitung dengan pajak penghasilan yang dibayarkan pada tahun berikutnya, tidak dapat dikenakan pajak atau dipotong sebagai biaya atau pengurangan, dan tidak dapat mengklaim pengembalian uang. Untuk melakukan kredit pajak luar, wajib pajak mengajukan permohonan kepada wajib pajak umum dengan cara:

a. Laporan pendapatan keuangan dari luar negeri.

b. Salinan pengembalian pajak dikirim ke luar negeri.

c. Pengembalian pajak asing.

Pengajuan permohonan pajak penghasilan luar negeri dilakukan bersamaan dengan penyampaian SPT tahunan. Atas permintaan Wajib Pajak, Direktur Jenderal Pajak dapat 
Jurnal Akuntansi Manajerial

ISSN (E): 2502-6704

Vol. 6, No. 1 Januari - Juni 2021: 1-24
Dipublikasikan oleh Fakultas Ekonomi dan Bisnis

Universitas 17Agustus 1945 Jakarta

http://journal.uta45jakarta.ac.id/index.php/JAM

memperpanjang jangka waktu penyampaian lampiran permohonan dengan alasan di luar kemampuan Wajib Pajak. Dalam hal terjadi perubahan jumlah penerimaan langsung dari LN, WP harus lakukan adjustment SPT tahunan yang bersangkutan melalui cara dengan menyerahkan dokumen terkait. Dalam hal ini penyesuaian karena pajak penghasilan dibayarkan lebih sedikit, maka bunga tidak terutang bunga sebagaimana dimaksud dalam Pasal 8 tahun (2) UU KUP. Namun, dalam hal penyesuaian menyebabkan pajak menjadi lebih dibayar, kelebihan jumlah bisa direstitusikan kepada WP after penghitungan dan pembayaran pajak lainnya.

kewajiban pajak luar negeri, jumlah yang dapat dimasukkan dalam jumlah $\mathrm{PPh}$ yang dibayarkan atau dibayarkan di luar negeri, tetapi tidak boleh melebihi batas maksimum yang diizinkan. PKP itu sama dengan penghasilan wajib pajak badan, tapi bukan Orang Pribadi (perorangan) karena itu PTKP atau yang disingkat Penghasilan Tidak Kena Pajak yang didefinisikan sebagai yang dibebaskan dari pengenaan pajak. Nominal pajak yang diakui tidak boleh sampai melebihi $\mathrm{PPh}$ berdasarkan tarif progresif pasal 17 yang terutang.

\section{Kasus pajak PPh pasal 24}

For example, PT Tiga Raja peroleh pendapatan di tahun 2019 sebagai berikut: Valuta asing (Valas) sebesar Rp 5.000.000.000,00 dengan nilai pajak sebesar $40 \%$. Operational Income di Indonesia yakni Rp. 1.000.000.000,00 dengan (BKPM) batas kredit pajak maksimum.

Solusi:

Nilai bersihnya yakni Rp. 5.000.000.000,00 + Rp 1.000.000.000,00 $=\mathrm{Rp}$ $6.000 .000 .000,00$

Adapun batasan kredit pajak terrendah dari 3, yakni:

1. $\mathrm{PPh}$ atas pendapatan di luar negeri adalah

$$
40 \% \times R p 5.000 .000 .000,00=R p 2.000 .000 .000,00
$$

2. (Rp. 5.000.000.000,00 : 6.000.000.000,00) x Rp.1.680.000.000,00

$$
=R p 1.400 .000 .000,00
$$


Jurnal Akuntansi Manajerial

ISSN (E): 2502-6704

Vol. 6, No. 1 Januari - Juni 2021: 1-24
Dipublikasikan oleh Fakultas Ekonomi dan Bisnis

Universitas 17Agustus 1945 Jakarta

http://journal.uta45jakarta.ac.id/index.php/JAM

3. Debt income tax (sesuai tarif progesif pasal 17) $=$

$$
R p 6.000 .000 .000,00 \times 28 \%=R p 1.680 .000 .000,00
$$

Dengan demikian, utang pajak yang disetujui berada di posisi ke-2 sebesar Rp $1.400 .000 .000,00$

Banyak perusahaan, khususnya pengusaha kena pajak yang belum memahami; mekanisme yang tepat guna melakukan pengkreditan pajak terhadap besarnya penghasilan kenapa pajak badan yang terutang, salah satunya menggunakan $\mathrm{PPh}$ Pasal 24 atau yang biasa disebut dengan KPLN yakni bila disingkat kredit pajak luar negeri. KPLN diilustrasikan sebuah PT. A menanamkan saham di XYZ Co. di Belgia senilai 20\%. Saat XYZ Co. melakukan pelaporan Corporate Income Tax (CIT) atau SPT Tahunan Badan yang berlaku di Negara Belgia tentu akan dipotong pajak sesuai dengan tariff Corporate Income Tax yang berlaku di Negara tersebut. Kemudian karena PT. A ikut memiliki saham sebesar 20\% di XYZ Co maka PT A berhak memperoleh deviden. Atas deviden tersebut nantinya dikenakan pajak atas deviden yang berlaku di Indonesia. Nah, pengenaan pajak atas deviden ini yang dijadikan sebagai KPLN dan dapat dimanfaatkan guna mengurangi besarnya KPLN. Dalam rangka mengkreditkan pajak di LN, tidak bisa langsung dilakukan saat melakukan pelaporan SPT Tahunan Badan. Tetapi harus melakukan korespodensi dengan cara kantor pelayanan pajak di mana perusahaan berdomisili. Pengajuan pengkreditan pajak luar negeri tersebut harus mendapatkan persetujuan dari kantor pajak terlebih dahulu baru bisa melakukan pengkreditan $\mathrm{PPh}$ atas deviden tersebut. Yang menjadi persoalan adalah apakah setiap perusahaan telah melakukan transaksi yang memicu pengenaan $\mathrm{PPh}$ pasal 24. Beberapa perusahaan dalam beroperasional terlibat dalam pemotongan PPh pasal 22, 23 dan 25. Sehingga perusahaan tersebut bisa memanfaatkan pengkreditan pajak penghasilan pasal 22, 23 dan 25 saja. Jika besarnya ketiga jenis pajak penghasilan tersebut dirasa telah membantu mengurangi besarya $\mathrm{PPh}$ terutang badan, tentu perusahaan tidak perlu menambah dari sektor Pajak Penghasilan dari kredit pajak luar negeri. Namun bila pada perusahaan terdapat PPh pasal 24, tentu sebaiknya dipakai PPh pasal 24 tersebut untuk menekan besarnya laba kena pajak perusahaan. 
Jurnal Akuntansi Manajerial

ISSN (E): 2502-6704

Vol. 6, No. 1 Januari - Juni 2021: 1-24
Dipublikasikan oleh Fakultas Ekonomi dan Bisnis

Universitas 17Agustus 1945 Jakarta

http://journal.uta45jakarta.ac.id/index.php/JAM

Sebuah perusahaan yang baik, tentunya perlu melakukan perencanaan pajak secara maksimal supaya dapat menekan laba kena pajak yang terlampau tinggi. Memang di satu sisi, perusahaan selalu berusaha untuk mendapatkan laba yang tinggi dari sisi akuntansi. Namun dari sisi pajak, laba yang tinggi bukan merupakan ide yang cemerlang. Perusahaan harus melakukan semaksimal mungkin supaya laba kena pajak berada pada titik terendah. Besar harapan perusahaan untuk menghasilkan sebuah laba kena pajak yang kecil karena dana yang available yang perusahaan maintain dapat digunakan sebagai cash flow bagi perusahaan yang nantinya bisa digunakan untuk keperluan lain dalam rangka memajukan perusahaan. Perusahaan yang memiliki konsultan pajak tentu bisa melakukan perencanaan pajak yang baik. Sehingga membawa perusahaan pada perusahaan yang semakin makmur namun tetap taat dan patuh terhadap kewajiban pajak. Direktorat jenderal pajak tetap memperoleh penerimaan pajak dari para pengusaha kena pajak, namun dari satu sisi pengusaha kena pajak tetap memperoleh keuntungan secara bisnis.

\section{Metode Mekanisme Penghitungan Pajak Penghasilan Pasal 24}

Berikut ilustrasi lain perhitungan PPh Pasal 24:

Misalkan PT ABC pada tahun 2017 menerima pendapatan di Indonesia senilai Rp 25.000.000.000,00 serta dari Singapura senilai Rp 10.000.000.000,00. Perkiraan pajak di singapura sebesar 20\%.Total penghasilan yang dicatat sebesar Rp35.000.000.000,00 (Penghasilan di Indonesia + penghasilan di Singapura)

Total utang Pajak: $25 \% \times R p$ 35.000.000.000,00 $=R p$ 8.750.000.000,00

$\mathrm{PPh}$ yang bagus untuk diapresiasi:

$$
\begin{gathered}
\frac{\text { Pendapatan luar negeri }}{\text { pendapatan kotor }} \times \text { Total pendapatan kotor } \\
\frac{R p 10.000 .000 .000,00}{R p 35.000 .000 .000,00} R p 8.750 .000 .000,00=R p 2.500 .000 .000,00
\end{gathered}
$$

Oleh karena itu, pajak penghasilan yang dibayarkan di luar negeri adalah Rp 2.500.000.000. Maka dari itu, jumlah yang terbatas ini pada akhirnya digunakan sebagai 
Jurnal Akuntansi Manajerial

ISSN (E): 2502-6704

Vol. 6, No. 1 Januari - Juni 2021: 1-24
Dipublikasikan oleh Fakultas Ekonomi dan Bisnis

Universitas 17Agustus 1945 Jakarta

http://journal.uta45jakarta.ac.id/index.php/JAM

pengurang pajak dalam negeri. Namun perlu diingat, jika Wajib Pajak ingin membayar pajak daerah, Perusahaan harus melaporkannya terlebih dahulu kepada Kepala Kantor Pelayanan Pajak (KPP) lalu melaporkannya pada SPT tahunan. Pelaporan lengkap dengan pengembalian pajak luar negeri dan SPT yang dilakukan oleh wajib pajak di luar negeri.

\section{Pembetulan SPT PPh Pasal 24}

Jika ada pembetulan pada laporan pajak luar negeri yang menyebabkan pajak luar negeri dilaporkan lebih tinggi pada Surat Pemberitahuan Tahunan, dan menyebabkan pajak luar negeri dibayar lebih sedikit, akan mengakibatkan lebih banyak pajak penghasilan dibayar di Indonesia. Dalam hal ini Wajib Pajak dapat melakukan penyesuaian sendiri dengan melakukan penyesuaian pada SPT. Jika penyesuaian dilakukan, bunga pajak tanpa bunga tidak akan dikumpulkan. Apabila terjadi pembetulan maka jumlah yang terutang di luar negeri akan lebih kecil dari jumlah yang dilaporkan ke SPT, sehingga akan mengakibatkan kelebihan pembayaran laporan pajak luar negeri. Pembetulan ini menghasilkan sedikit pajak penghasilan yang dikenakan di Indonesia. Akibatnya, PPh dibayar lebih. Kelebihan ini dapat diganti setelah dihitung dengan kewajiban pajak lainnya.

\section{Persyaratan Kontrol Pajak Luar Negeri}

Sebagaimana telah disinggung pada poin sebelumnya, wajib pajak yang telah membayar pajaknya di luar negeri, kemudian ingin meminjam ke Indonesia, harus mengajukan ke Kantor Pelayanan Pajak (KPP) terlebih dahulu. Permohonan tersebut kemudian dilaporkan bersama dalam Laporan Tahunan SPT dengan menyerahkan sejumlah dokumen yang menyatakan:

1. Laporan keuangan dari luar negeri

2. Fotokopi SPT (Surat Pemberitahuan) sudah dilaporkan ke luar negeri.

3. Pengembalian pajak asing.

Untuk mengurangi beban pendapatan luar negeri, pendapatan luar negeri dapat dikenakan pajak atas semua uang wajib pajak lokal. Apakah setelah itu apakah PPh Pasal 24 dapat dimasukkan dalam undang-undang yang terutang di 
Jurnal Akuntansi Manajerial

ISSN (E): 2502-6704

Vol. 6, No. 1 Januari - Juni 2021: 1-24
Dipublikasikan oleh Fakultas Ekonomi dan Bisnis

Universitas 17Agustus 1945 Jakarta

http://journal.uta45jakarta.ac.id/index.php/JAM

Indonesia? Jawabannya tentu saja. Namun, perpajakan harus untuk tahun yang sama. Selain itu, jumlah kredit pajak yang terutang sama dengan jumlah pajak yang dibayarkan atau dibayarkan di luar negeri.

\section{Bagaimana cara menahan Pembayaran Pajak Luar Negeri}

Berikut hal-hal yang perlu Perusahaan ketahui tentang proses apresiasi PPh yang dibayarkan di luar negeri:

1. Pajak penghasilan yang dibayarkan di luar negeri dapat ditambahkan ke pajak penghasilan yang dibayarkan di Indonesia.

2. Penanaman modal $\mathrm{PPh}$ yang dibayarkan ke luar negeri ( $\mathrm{PPh}$ Pasal 24) dilakukan pada tahun periode pajak dikala pendapatan dari luar negeri digabungkan dengan pendapatan di negara Indonesia.

Adapun jumlah maksimal Pajak Penghasilan pasal 24 yang bisa dikalkulasikan yakni nominal minimal $\mathrm{PPh}$ yang dibayarkan di negara lain dan jumlah yang dihitung berdasarkan rata-rata devisa dan semua Pajak Penghasilan, atau jumlah maksimum Pajak Penghasilan atas semua Pajak Penghasilan dalam hal rumah. Kerugian (Pendapatan dari luar negeri lebih tinggi dari jumlah pendapatan yang dibebankan)

Jika $\mathrm{m}=$ pendapatan asing dari sebagian besar negara, maka kalkulasi pasal 24 untuk setiap negara

Pendapatan kena pajak berdasarkan Pajak Pendapatan Final (Bagian 4 bagian 2) dan / atau pendapatan pajak alternatif tidak dapat digabungkan dengan pendapatan lain, baik yang tersedia di dalam maupun di luar negeri. Dalam hal jumlah PPh yang dibayarkan di LN melebihi Pasal 24 Pajak Penghasilan, kelebihan jumlah tersebut tidak dapat diperhitungkan pada tahun berikutnya, tidak dapat dibebankan sebagai biaya, dan tidak dapat dikembalikan. Dalam mengajukan kredit Pajak Penghasilan di LN, WP diwajibkan untuk ajukan ke Kantor Pelayanan Pajak tempat dimana PKP itu berdomisili serta melaporkan SPT, yang terdiri dari:

\section{Financial statement dari LN,}


Jurnal Akuntansi Manajerial

ISSN (E): 2502-6704

Vol. 6, No. 1 Januari - Juni 2021: 1-24
Dipublikasikan oleh Fakultas Ekonomi dan Bisnis

Universitas 17Agustus 1945 Jakarta

http://journal.uta45jakarta.ac.id/index.php/JAM

2. Fotocopy Retur produk dari LN,

3. Bukti bukti penerimaan Pajak Penghasilan di Luar Negeri.

Atas request WP, Kepala Kantor Pelayanan Pajak boleh menambah masa penempelan seperti yang disampaikan di atas sebab alasan tertentu seperti di luar kemampuan WP. Dalam kondisi terjadi beberapa mekanisme perubahan nominal pendapatan dari LN, Wajib Pajak harus melakukan adjustment terkait SPT Tahunan Badan yang bersangkutan melalui mekanisme penyerahan dokumendokumen yang berkaitan dengan perubahan tersebut. Jika penyesuaian SPT menghasilkan SPT yang lebih rendah, maka pendapatan yang lebih rendah tersebut tidak akan dikenakan denda bunga. Apabila penyesuaian SPT mengakibatkan kelebihan pembayaran, kelebihan ini boleh direstitusikan kepada WP setelah dilakukan penghitungan dan SPT lainnya.

\section{Deviden Pajak Penghasilan}

Proses pemotongan pajak yang dipotong dari dividen yang diterima dari BULN Bursa saham diatur langsung oleh tahun pajak / deductible. Hal tersebut diatur dalam Pasal 7 Peraturan Menteri Keuangan No. 107/PMK.03 tahun 2017 mengenai penetapan periode perolehan serta basic untuk melakukan perhitungan WPDN terkait transaksi bisnis di LN pada usaha lain yang telah menjual sahamnya di lantai bursa. Untuk selanjutnya wajib pajak daerah yang menyerahkan pajak penghasilan wajib menyampaikan penghitungan jumlah pajak yang dibayarkan atau dipotong dari dividen yang diterima dari BULN Non Bursa Efek langsung kepada Direktur Jenderal dengan menyerahkan dokumen sebagai berikut:

1. Laporan keuangan

2. Fotokopi Surat Pemberitahuan Tahunan, dalam hal wajib menyampaikan Surat Pemberitahuan Tahunan

3. Perhitungan atau penurunan margin keuntungan selama 5 tahun terakhir. 
Jurnal Akuntansi Manajerial

ISSN (E): 2502-6704

Vol. 6, No. 1 Januari - Juni 2021: 1-24
Dipublikasikan oleh Fakultas Ekonomi dan Bisnis

Universitas 17Agustus 1945 Jakarta

http://journal.uta45jakarta.ac.id/index.php/JAM

Bukti pengembalian pajak penghasilan atau bukti pemotongan pajak penghasilan atas dividen yang diterima. Pengiriman angka dilakukan bersamaan dengan penyerahan Daftar Pendapatan Tahunan

\section{KESIMPULAN}

Kesimpulan dari artikel ini adalah bahwa pajak yang dibayarkan di luar negeri atas penghasilan luar negeri diterima oleh wajib pajak daerah. Formulir pajak pendapatan pasal 24 tahun ini dapat dimasukkan dalam total pajak terhutang untuk tahun pajak tersebut.

Untuk memberikan perlakuan perpajakan yang adil antara penghasilan atau penghasilan luar negeri dari Indonesia, jumlah pajak yang dibayarkan atau dibayarkan di luar negeri dapat dikenakan pajak di Indonesia tetapi tidak boleh melebihi jumlah pajak yang dibayarkan atas seluruh penghasilan di Indonesia.

Penghitungan penghasilan tidak kena pajak tidak termasuk pembayaran di luar negeri selain kewajiban pajak yang diperbolehkan, sehingga kelebihannya tidak dapat dihitung dengan pajak penghasilan yang dibayarkan pada tahun berikutnya, tidak dapat dikenakan pajak atau dipotong sebagai biaya atau pengurangan, dan tidak dapat mengklaim pengembalian uang. 
Jurnal Akuntansi Manajerial

ISSN (E): 2502-6704

Vol. 6, No. 1 Januari - Juni 2021: 1-24
Dipublikasikan oleh Fakultas Ekonomi dan Bisnis

Universitas 17Agustus 1945 Jakarta http://journal.uta45jakarta.ac.id/index.php/JAM

\section{DAFTAR PUSTAKA}

Peraturan Menteri Keuangan No. 107 / PMK.03 / 2017

Peraturan Menteri Keuangan No. 192 / PMK.03 / 2018

Wuarmanuk, BM. 2019. Menyoal e-SPT PPh Pasal 23/ 26 dan PKP Terdaftar Terhadap Penerimaan PPh 23/ 26 Serta Tax Planning Sebagai Variabel Intervening, Vol. IV. Jakarta: Jurnal Akuntansi Manajerial Universitas 17 Agustus

DDTC. 2017. Contoh Soal Perhitungan PPh Pasal 24. Diakses dari https://news.ddtc.co.id/contoh-soal-perhitungan-pph-pasal-24-9192 ， tanggal 1 Desember 2020

Cermati.com. 2016. PPh Pasal 24, Ini Penjelasan dan Perhitungannya. Diakses dari https://www.cermati.com/artikel/pph-pasal-24-ini-penjelasan-dan-perhitungannya tanggal 7 Desember 2020 